\title{
Thermal Resistance between Solidifying Steel Shell and Continuous Casting Mold with Intervening Flux Film
}

\author{
Hiroyuki SHIBATA, Koichi KONDO, Mikio SUZUKI and Toshihiko EMI \\ Institute for Advanced Materials Processing, Tohoku University, Katahira, Aoba-ku, Sendai, Miyagi-ken, 980-77 Japan.
}

(Received on April 23, 1996; accepted in final form on November 12, 1996)

\begin{abstract}
Conductive thermal resistance from solidifying steel shell through mold flux to continuous casting mold was investigated in bench tests. Thermal diffusivities of six mold fluxes used in continuous casting of steels were determined in glassy, crystalline and molten states with a laser flash method. Interfacial thermal resistance between the solidifying mold fluxes and copper mold was also investigated by pouring the molten fluxes onto copper mold and measuring transient heat transfer to the mold. The surface morphology of solidified fluxes in contact with the mold was observed with a stylus type profile meter and related to the interfacial thermal resistance. Thermal diffusivity of glassy state (ca. $4.5 \times 10^{-7} \mathrm{~m}^{2} \mathrm{~s}^{-1}$ ) and molten state (ca. $5 \times 10^{-7} \mathrm{~m}^{2} \mathrm{~s}^{-1}$ ) was insensitive to chemical composition and temperature, while that of crystalline state was higher $\left(5.8-7.8 \times 10^{-7} \mathrm{~m}^{2} \mathrm{~s}^{-1}\right.$ at room temperature) and decreased with increasing temperature, reaching similar value to that for glassy and molten state at high temperatures. The surface morphology consisted of large cells on which small cells were superimposed. Observed interfacial thermal resistance increased with increasing height of the large cells, contributing more than $50 \%$ of the total conductive heat transfer resistance and being a significant factor to control the heat transfer between the solidifying steel shell and the mold.
\end{abstract}

KEY WORDS: thermal diffusivity; interfacial thermal resistance; glassy state; crystalline state; molten state; mold flux; continuous casting; steels.

\section{Introduction}

Mold flux utilized in continuous casting of steel infiltrates the mold/solidifying steel shell boundary, controlls the heat transfer and provides the lubrication between the shell and mold. Decreasing the heat transfer through mold flux film at the mold/shell boundary has been effective to prevent the surface cracks occurring in casting peritectic middle carbon steels, ${ }^{1,2)}$ although the mechanism for the decrease in the heat transfer is not well understood. Heat transfer from the mold flux to copper mold and thermal diffusivity of the mold flux have been measured in this study to investigate the thermal resistance between the shell and mold across the mold flux.

The total heat flux, $q_{\text {total }}$, from the shell to mold is the sum of radiative $\left(q_{\mathrm{rad}}\right)$ and conductive $\left(q_{\text {cond }}\right)$ components. The flux melt infiltrated between the solidifying steel shell and mold forms molten, crystalline and glassy layers in this order from the shell to the mold. Corresponding total thermal resistance, $R_{\text {total }}$, also consists of radiative and conductive components given by

$$
\frac{1}{R_{\text {total }}}=\frac{1}{R_{\text {rad }}}+\frac{1}{R_{\text {cond }}}
$$

where $\frac{1}{R_{\text {cond }}}=\frac{1}{R_{\text {int }}+R_{\mathrm{g}}+R_{\mathrm{c}}+R_{\mathrm{L}}+R_{\mathrm{L} / \mathrm{s}}}$.

The conductive component of the thermal resistance is represented by the second term on the right hand side of Eq. (1), where $R_{\mathrm{L} / \mathrm{s}}$ is the interfacial thermal resistance between the flux melt and the shell. As the flux melt wets the shell, $R_{\mathbf{L} / \mathrm{S}}$ value should be close to zero. In this study, therefore, only the thermal resistance of molten flux $\left(R_{\mathrm{L}}\right)$, crystalline flux $\left(R_{\mathrm{c}}\right)$ and glassy flux $\left(R_{\mathrm{g}}\right)$, has been determined by measuring the corresponding thermal diffusivities. The interfacial thermal resistance, $R_{\text {int }}$, between the mold flux and the mold has also been investigated.

\section{Experimental Procedure}

\subsection{Chemical Composition of Mold Fluxes}

Chemical composition of the mold fluxes investigated is shown in Table 1. Two series of commercially popular fluxes, each for three steel grades, i.e., middle carbon, low carbon and ultra low carbon steel, were selected. For middle carbon steels, MC or MC-S is used where the viscosity of $\mathrm{MC}-\mathrm{S}$ is lower than that of $\mathrm{MC}$. For low carbon steels, LC or LC-S is used where the viscosity and basicity are different from each other as shown in Table 1. When ultra low carbon steel is cast, ULC or ULC-S is used where the viscosity of the two is nearly the same, but the basicity of ULC-S is larger than that of ULC.

\subsection{Measurement of Thermal Diffusivity}

Each mold flux was melted at $1673 \mathrm{~K}$ in a Pt crucible, quenched on a $\mathrm{Cu}$ plate and annealed at $773 \mathrm{~K}$ for $30 \mathrm{~min}$ to obtain glassy specimens. The glassy specimens were heated to $1073 \mathrm{~K}$ for $30 \mathrm{~min}$ to obtain crystalline specimens. Both specimens were machined to disks of $1 \mathrm{~mm}$ thickness and $10 \mathrm{~mm}$ diameter for the measurement of thermal diffusivity which was carried out under vacuum with a laser flash method ${ }^{3)}$ at $300-773 \mathrm{~K}$ for the 
Table 1. Chemical composition and properties of mold flux.

\begin{tabular}{|c|c|c|c|c|c|c|}
\hline Mold flux & MC & LC & ULC & $M C-S$ & $\mathrm{LC}-\mathrm{S}$ & ULC-S \\
\hline $\begin{array}{l}\text { Steel grade } \\
\text { applied }\end{array}$ & $\begin{array}{l}\text { Middle } \\
\text { carbon }\end{array}$ & $\begin{array}{c}\text { Low } \\
\text { carbon }\end{array}$ & \begin{tabular}{|c|}
$\begin{array}{c}\text { Ultra low } \\
\text { carbon }\end{array}$ \\
\end{tabular} & $\begin{array}{l}\text { Middle } \\
\text { carbon }\end{array}$ & $\begin{array}{c}\text { Low } \\
\text { carbon }\end{array}$ & \begin{tabular}{|c|}
$\begin{array}{c}\text { Ultra low } \\
\text { carbon }\end{array}$ \\
\end{tabular} \\
\hline $\mathrm{SiO}_{2}$ & 34.0 & 30.5 & 30.1 & 31.8 & 35.0 & 39.7 \\
\hline $\mathrm{CaO}$ & 43.7 & 32.6 & 35.0 & 44.8 & 33.8 & 32.4 \\
\hline $\mathrm{Al}_{2} \mathrm{O}_{3}$ & 3.0 & 2.5 & 5.3 & 3.7 & 6.4 & 6.0 \\
\hline $\mathrm{Fe}_{2} \mathrm{O}_{3}$ & 0.4 & 1.3 & 1.5 & 0.4 & 0.7 & 0.8 \\
\hline $\mathrm{Na}_{2} \mathrm{O}$ & 6.6 & 13.0 & 3.6 & 7.3 & .11 .2 & 9.7 \\
\hline $\mathrm{MgO}$ & 5.1 & 1.5 & 6.8 & 1.9 & 2.3 & 2.4 \\
\hline $\mathrm{MnO}$ & - & 6.0 & 2.3 & 0.1 & 0.1 & 0.1 \\
\hline $\mathrm{TiO}_{2}$ & - & - & 4.7 & 0.1 & 0.1 & 0.1 \\
\hline $\mathrm{K}_{2} \mathrm{O}$ & - & . & - & 0.3 & 0.5 & 0.7 \\
\hline $\mathrm{B}_{2} \mathrm{O}_{3}$ & - & - & 5.7 & . & - & . \\
\hline $\mathrm{Li}_{2} \mathrm{O}$ & $\dot{.}$ & 3.1 & - & 3.9 & 4.6 & 5.5 \\
\hline $\mathrm{F}$ & 8.8 & 10.8 & 5.9 & 9.9 & 8.4 & 5.0 \\
\hline $\mathrm{CaO} / \mathrm{SiO}_{2}$ & 1.29 & 1.07 & 1.16 & 1.41 & 0.96 & 0.82 \\
\hline $\begin{array}{l}\text { Viscosity } \\
\text { (Pa.s at 1573K) }\end{array}$ & 0.18 & $0.04^{*}$ & 0.15 & 0.05 & 0.09 & 0.20 \\
\hline $\begin{array}{l}\text { Softening } \\
\text { point }(\mathrm{K})\end{array}$ & 1413 & 1243 & 1253 & 1303 & 1203 & 1228 \\
\hline $\begin{array}{l}\text { Solidifying } \\
\text { point(K) }\end{array}$ & 1473 & 1353 & 1193 & - & - & - \\
\hline $\begin{array}{l}\text { Crystalization } \\
\text { temperature }(\mathrm{K})\end{array}$ & - & - & - & 1428 & 1303 & 1253 \\
\hline
\end{tabular}

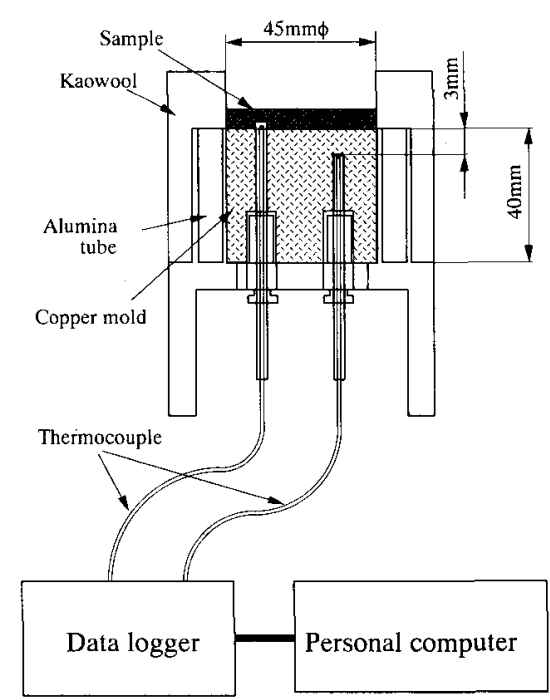

Fig. 1. Schematic of experimental apparatus for measuring interfacial thermal resistance.

glassy specimens and at $300-1073 \mathrm{~K}$ for the crystalline specimens. Specimens were coated with a thin layer of carbon to avoid absorption of laser energy inside them. The thermal diffusivity of flux melt $(1.8 \mathrm{~g})$ was measured at $1523-1673 \mathrm{~K}$ by using the differential three layered laser flash technique developed by Ohta et al. ${ }^{4,5}$

\subsection{Measurement of Interfacial Thermal Resistance and Surface Morphology}

Figure 1 shows the experimental setup for measuring the interfacial thermal resistance between the mold and flux. Mold flux $(30 \mathrm{~g})$ was melted at $1673 \mathrm{~K}$ and poured onto the $\mathrm{Cu}$ mold. Temperature changes were simultaneously measured at the mold side surface of solidifying flux by an R-type thermocouple and at the depth of $3 \mathrm{~mm}$ away from the surface of the mold by a K-type thermocouple. Heat flux at the surface was calculated from the temperature change at the depth of $3 \mathrm{~mm}$. The temperature change at the surface of the mold was then determined from the calculated heat flux. The interfacial thermal resistance was calculated from these data.

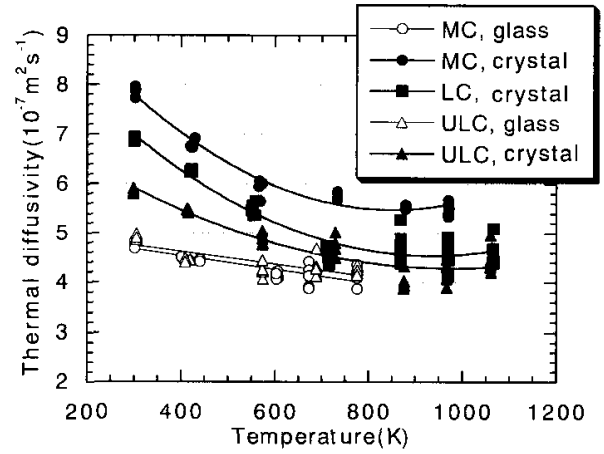

Fig. 2. Thermal diffusivity of glassy and crystalline mold fluxes for MC, LC and ULC.

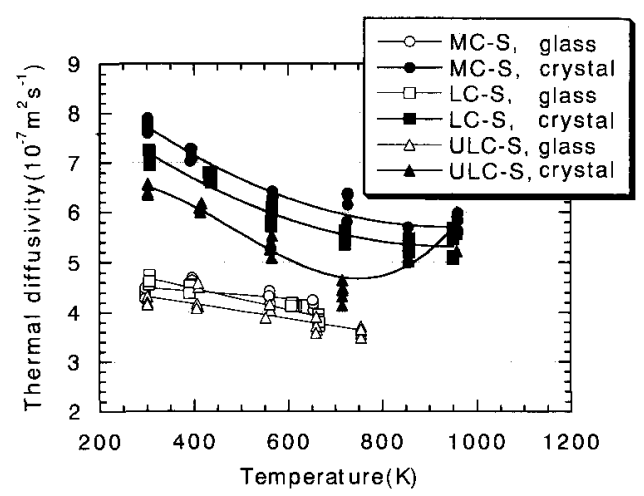

Fig. 3. Thermal diffusivity of glassy and crystalline mold fluxes for MC-S, LC-S and ULC-S.

Morphology of the surface of solidified mold fluxes in contact with the $\mathrm{Cu}$ mold was determined by using a stylus type profile meter and was related to the interfacial thermal resistance.

\section{Results}

\subsection{Thermal Diffusivity of Mold Fluxes}

Thermal diffusivities of glassy and crystalline fluxes are shown in Figs. $2^{6)}$ and 3 . The glassy state for LC specimen was not available due to very rapid crystallization. In the glassy state, the thermal diffusivities are found insensitive to chemical composition and temperature, whereas in the crystalline state, they decrease with increasing temperature. The thermal diffusivity of crystalline MC exhibits the highest value, $c a .7 .8 \times 10^{-7}$ $\mathrm{m}^{2} \mathrm{~s}^{-1}$ at $300 \mathrm{~K}$. The thermal diffusivities get slightly smaller in the order of MC, LC and ULC. As shown in Fig. 3, the diffusivities of the second set of mold fluxes are almost the same as those of the first set. The diffusivity for the crystalline state is much higher, 1.3-1.6 times, at lower temperatures than that of the glassy or molten states, decreasing with increasing temperature to $1.0-1.4$ times at $600-1000 \mathrm{~K}$. This tendency is similar to the previous observation by Shibata et al. ${ }^{7)}$

The thermal diffusivities of flux melts shown in Fig. 4 are scattered because the effect of radiative heat flux was not considered in this measurement. However, the gross average is $c a .5 \times 10^{-7} \mathrm{~m}^{2} \mathrm{~s}^{-1}$, insensitive to chemical composition and temperature. This is reasonable since the structure of the flux melt should be similar to that of the glassy state. 


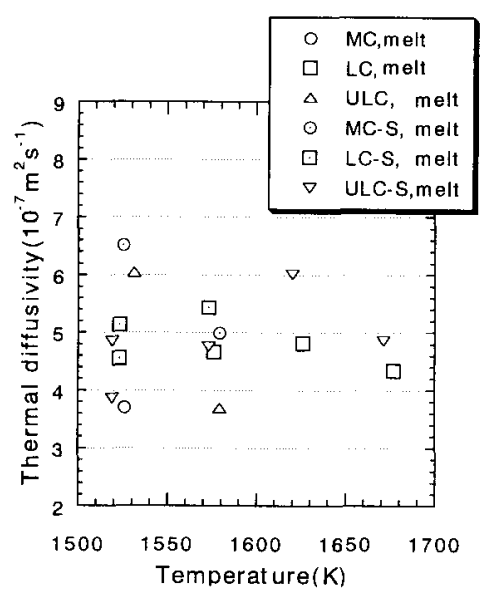

Fig. 4. Thermal diffusivity of molten mold fluxes.

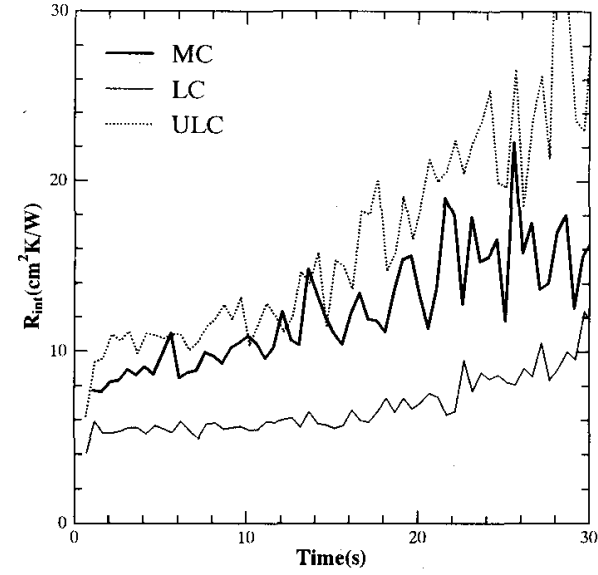

Fig. 5. Calculated interfacial thermal resistance for MC, LC and ULC at the interface between the mold flux and mold.

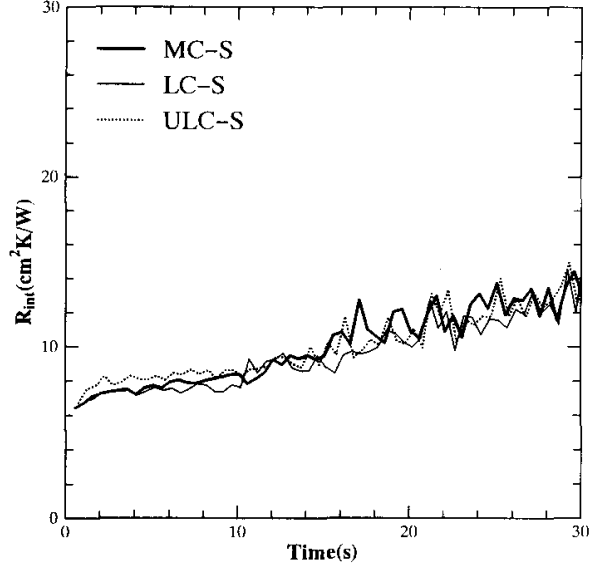

Fig. 6. Calculated interfacial thermal resistance for MC-S, LC-S and ULC-S at the interface between the mold flux and mold.

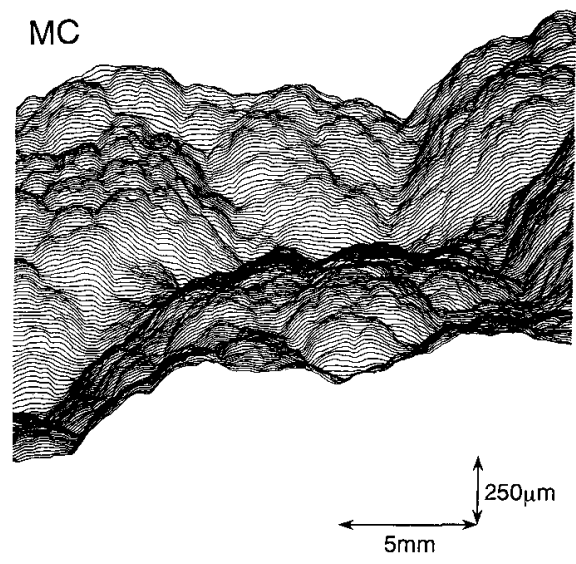

Fig. 7. Surface morphology of solidified mold flux in contact with the mold.

Table 2. Average height of large cells.

\begin{tabular}{|c|c|c|c|c|c|c|}
\hline Moid flux & MC & LC & ULC & MC-S & LC-S & ULC-S \\
\hline Average height $(\mu \mathrm{m})$ & 156 & 101 & 167 & 73 & 86 & 104 \\
\hline
\end{tabular}

\subsection{Interfacial Thermal Resistance and Surface Mor- phology}

Flux melt was poured onto the $\mathrm{Cu}$ mold plate at zero time. As shown in Fig. 5, the interfacial thermal resistance arises within $1 \mathrm{~s}$ and increases with time, exhibiting the highest value for ULC and the lowest for LC. In the second set of fluxes, the thermal resistance was found to be insensitive to chemical composition as shown in Fig. 6. Observation of the cross section of solidified fluxes by optical microscope showed that the area close to the surface was glassy for MC, ULC, MC-S and ULC-S, and was partially crystalline for LC and LC-S.

The morphology of the MC flux surface, which was in contact with the $\mathrm{Cu}$ mold, is shown in Fig. 7.6) The surface comprises large cells each with a diameter of $5-10 \mathrm{~mm}$ on which small cells $2-3 \mathrm{~mm}$ in diameter are superimposed. The large cells, which form an air gap in between the mold and the solidified flux, are responsible for the thermal resistance. The average height of the large cells for the six fluxes is shown in Table 2. The average for MC and ULC is found to be 156-167 $\mu \mathrm{m}, 1.5-2.3$ times larger than that for other fluxes.

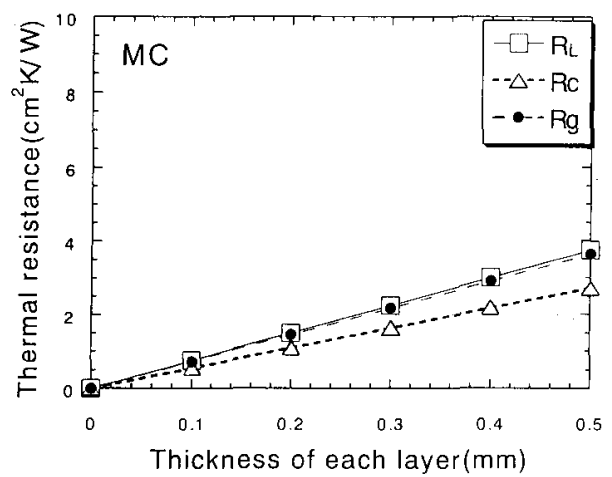

Fig. 8. Relationship between the calculated conductive thermal resistance and the thickness of each layer.

\section{Discussion}

Thermal resistances, $R_{\mathrm{g}}, R_{\mathrm{c}}$ and $R_{\mathrm{L}}$, are derived in the following manner from the measured thermal diffusivities. The thermal resistance is represented by

$$
R=\frac{d}{\lambda}, \quad \lambda==\alpha \rho C_{\mathrm{p}}
$$

where $d$ is thickness, $\lambda$; thermal conductivity, $\rho$; density $\left(2.71 \times 10^{3} \mathrm{~kg} \mathrm{~m}^{-3}\right), \alpha$, thermal diffusivity and $C_{\mathrm{p}}$ is heat capacity $\left(1.23 \times 10^{3} \mathrm{~J} \mathrm{~kg}^{-1} \mathrm{~K}^{-1}\right)$. The values of heat capacity and density at $923 \mathrm{~K}$ were obtained from the literature. ${ }^{8)}$ Average values of thermal diffusivity in glassy state at $673 \mathrm{~K}$ and in crystalline state at $973 \mathrm{~K}$ were used for calculating $R_{\mathrm{g}}$ and $R_{\mathrm{c}}$. Ohta et $a l^{5)}$ obtained the thermal diffusivity of flux melts to be $4 \times 10^{-7} \mathrm{~m}^{2} \mathrm{~s}^{-1}$, in which the contribution of radiative heat flux was corrected by considering the optical properties of the glassy fluxes. This value was used to calculate $R_{\mathrm{L}}$, accordingly. The thermal resistances, $R_{\mathrm{g}}, R_{\mathrm{c}}$ and $R_{\mathrm{L}}$ are shown in Fig. 8 for varying thickness of fluxes where $R_{\mathrm{c}}$ is a little smaller than $R_{\mathrm{g}}$ and $R_{\mathrm{L}}$. It is very difficult to estimate the precise thickness of each layer in a continuous casting mold. However, assuming that the thickness of each layer is $0.3 \mathrm{~mm}$, total thermal resistance is calculated to be $6 \mathrm{~cm}^{2} \mathrm{~K} \mathrm{~W}^{-1}$ for all mold fluxes except for $\mathrm{LC}$.

The fact that the interfacial thermal resistance arises in $1 \mathrm{~s}$ as shown in Fig. 5 indicates that an air gap is 


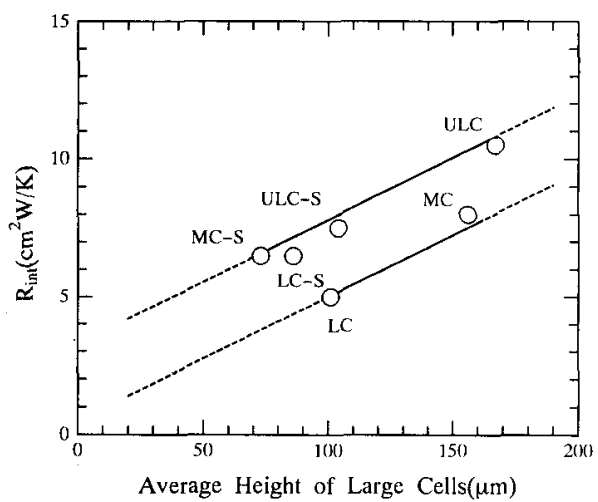

Fig. 9. Influence of the height of large cells on the interfacial thermal resistance.

formed in between the solidified flux and the mold at this time. The resistance then remains almost constant up until $5 \mathrm{~s}$, implying that the surface roughness is kept constant for a period of $4 \mathrm{~s}$. After $5 \mathrm{~s}$, global bending of the whole specimen may have taken place. Accordingly, the interfacial thermal resistance increases with time in this period. The resistance at $5 \mathrm{~s}$ is plotted against the average height of the large cells as shown in Fig. 9. The resistance values are in good agreement with those previously reported by Nakato et al. ${ }^{91}\left(3-9 \mathrm{~cm}^{2} \mathrm{~K} \mathrm{~W}^{-1}\right)$, Yamauchi et al. ${ }^{10)}\left(4-8 \mathrm{~cm}^{2} \mathrm{KW}^{-1}\right)$ and Watanabe et al. ${ }^{11)}\left(6-8 \mathrm{~cm}^{2} \mathrm{~K} \mathrm{~W}^{-1}\right)$. The $R_{\text {int }}$ increases with increasing height of the large cells, indicating a substantial contribution of $R_{\text {int }}$ to the overall resistance for the heat transfer from the solidifying shell to the mold across the mold flux.

The fraction of $R_{\text {int }}$ at $5 \mathrm{~s}$, which is at least $c a .5 \mathrm{~cm}^{2} \mathrm{~K}$ $\mathrm{W}^{-1}$, in the conductive component is almost as large as $50 \%$. When the flux gets thinner, the percentage can exceed $50 \%$ since the interfacial thermal resistance was found in separate experiments not to be affected by the thickness of mold flux up to $36 \mathrm{~mm}$ (static pressure applied by this thickness of the flux melt is similar to that $14 \mathrm{~mm}$ below the meniscus of steel melt in continuous casting mold).

The contribution of radiative heat flux to the total heat flux was estimated by Ichihashi et al. ${ }^{12)}$ to be $27 \%$ for the flux melts and $6 \%$ for the solidified flux in the continuous casting of round billet. The contribution of conductive component discussed in the present study is, therefore, considered to comprise the dominant fraction of the total heat flux. In this context, increasing the interfacial thermal resistance by designing appropriate mold flux offers a meaningful way to reduce the overall heat transfer from the shell to mold. It should be mentioned, however, that designing mold flux which easily crystallizes also provides a supplemental way to reduce the heat transfer by decreasing radiative heat transfer via scattering of radiation at the crystal boundaries.
With this regard, determination of the fraction of radiative component is underway by measuring optical properties of the fluxes with FTIR.

\section{Conclusion}

Thermal diffusivities of six mold fluxes were determined in glassy, crystalline and molten states and interfacial thermal resistances at the mold fluxes/mold boundaries were derived. The results are summarized as follows:

(1) Thermal diffusivities of glassy (ca. $4.5 \times 10^{-7}$ $\left.\mathrm{m}^{2} \mathrm{~s}^{-1}\right)$ and molten $\left(c a .5 \times 10^{-7} \mathrm{~m}^{2} \mathrm{~s}^{-1}\right)$ mold fluxes are about the same and insensitive to chemical composition and temperature.

(2) Thermal diffusivity of crystalline mold fluxes is much higher, $5.8-7.8 \times 10^{-7} \mathrm{~m}^{2} \mathrm{~s}^{-1}$, and decreases with increasing temperature.

(3) Interfacial thermal resistance increases with increasing surface roughness as represented by the average height of the large cells on the mold side surface of the solidified flux. This resistance accounts for a substantial fraction of the overall resistance for the heat transfer in continuous casting mold.

\section{Acknowledgements}

The authors thank the Ministry of Education, Science and Culture of Japan (grant-in-aid 07219202), Kawasaki Steel Corp. and Nippon Steel Corp. for their financial support.

\section{REFERENCES}

1) K. Nakajima, S. Hiraki, T. Kanazawa and T. Murakami: CAMP-ISIJ, 1 (1992), 1221.

2) H. Yasunaka, S. Koyama, H. Matuda and K. Matuo: Proc. the 4th Int. Conf. Molten Slags and Fluxes, ISIJ, Tokyo, (1992), 409.

3) W. J. Parker, R. J. Jenkins, C. P. Butler and A. L. Abbott: $J$. Appl. Phys., 32 (1961), 1979.

4) H. Ohta, K. Nakajima, M. Masuda and Y. Waseda: Proc. the 4th Int. Conf. Molten Slags and Fluxes, ISIJ, Tokyo, (1992), 421.

5) H. Ohta, M. Masuda, K. Watanabe, K. Nakajima, H. Shibata and Y. Waseda: Tetsu-to-Hagané, 80 (1994), 463.

6) K. Kondo, H. Shibata, M. Suzuki and T. Emi: CAMP-ISIJ, 8 (1995), 165 .

7) H. Shibata, T. Emi, Y. Waseda, K. Kondo. H. Ohta and K. Nakajima: Tetsu-to-Hagané, 82 (1996), 504.

8) R. Taylor and K. C. Mills: Ironmaking Steelmaking, 15 (1988), 187.

9) H. Nakato, M. Ozawa, K. Kinoshita, Y. Habu and T. Emi: Tetsu-to-Hagané, 67 (1981), 1200.

10) A. Yamauchi, K. Sorimachi, T. Sakuraya and T. Fujii: Tetsuto-Hagané, 79 (1993), 167.

11) K. Watanabe, H. Okamoto, M. Suzuki, H. Kondou and T. Shiomi, Abstracts 79th Steelmaking and 55th Ironmaking Conf., ISS-AIME, (1996), 92.

12) H. Ichihashi, M. Kawamoto, T. Tsukaguchi, N. Nishida, T. Kanazawa and S. Hiraki: The 19th Committee (Solidification-53), the Japan Society for the Promotion of Science (JSPS), Rep. No. 19-11594, (1995) 